Czechoslovak Socialist Republic. The introduction by L. Stoll, official spokesman for Czechoslovak literary Marxism, is the publication's imprimatur.

The book is roughly divided into three sections: articles and essays related to the music of B. Smetana, those concerning the Czech classics of the nineteenth century, and, finally, those guided or influenced by Marxism. (Nejedly's major scholarly work, his study on the Hussite song, is not included in the anthology.) The first essay, on Otakar Hostinský (1907), touches upon Smetana's music as do "Karel Sabina" (1908), and "Max Brod, Uber die Schönheit hässlicher Bilder" (1915). It was Nejedlý who made popular Max Brod's comment: "Smetana made the Vltava flow in G major."

Nejedly's partisan treatment of Czech classics includes Jirásek, Hálek, Rais, and others. However, Nejedly's polemical tone has lost the sharp edge which it had at the turn of the century-when decadence and symbolism were at their peak. In the years following World War I, when new trends in art and literature were in full swing, Nejedlýs opinion of Alois Jirásek, a writer of popular historical novels, as the foremost Czech writer seemed to border on naiveté. After 1945, however, Nejedly's innate conservative taste became the order of the day and he assumed the position of arbiter, comparable to Gorky's position in Russia.

The third section of the volume contains articles on prominent Czech scholars who were Nejedly's contemporaries. The articles include an interesting contribution on the matter of Hanka's falsification of Czech medieval manuscripts (1906); portraits of J. Goll (1906), J. Gebauer (1907), F. Cáda (1918), and K. Krofta (1936); and later discussions of Communist Party members Julius Fučík (a writer) and Nezval and Wolker (both poets). In this section we are also exposed to the world of socialist realism and its policies. We find an essay praising $O p$ timisticheskaia tragediia (1935), and a devastating criticism of Karel Capek's The Life of Insects (1922). Capek's obituary, however, written in 1938, praises his democratic attitude because in the late thirties Capek was in good standing with Soviet Russia. In short, literary issues of the first half of the century in Czechoslovakia stand out with clarity and authenticity, and their relation to the development of socialist realism, as it grew out of the politico-cultural situation of Czech intellectual history, becomes apparent.

The book has an afterword by J. Dvořák and includes an excellent commentary and bibliography.

Milada SoučKová

Cambridge, Massachusetts

\title{
STAATSVERWALTUNG UND KIRCHLICHE AUTORITÄT IM 18. JAHR- HUNDERT: DAS PROBLEM DER ZENSUR IN DER THERESIANI- SCHEN REFORM. By Grete Klingenstein. Österreich Archiv. Schriftenreihe des Instituts für Osterreichkunde. Munich: R. Oldenbourg Verlag, 1970. 235 pp. DM 22, paper.
}

The focal point of Dr. Klingenstein's treatise, indicated by the subtitle, is introduced at length and embellished by a host of informative comments on the relation of church and state in early modern Austria. Using the issue of press censorship as an exemplary framework, the author examines in selective fashion the complex interweaving of ecclesiastic and secular authority from the Counter Reformation to the Josephinist epoch. 
Klingenstein draws on a variety of sources, mainly from Viennese and Italian archives, to support a limited challenge to traditional views on the primacy of the church in establishing and supervising censorship. She believes that after the Tridentine council the civil government, specifically the provincial Stände, had the responsibility for censorship of the printed word. Only later, in the seventeenth century, was this task delegated in part-never entirely-to the Jesuit-controlled university in Vienna. By the latter part of the reign of Charles VI (1711-40), dissatisfaction at court with the dilatory and slipshod workings of the university faculties had begun to promote a third force for the administration of censorship: the secular clergy headed by the Vienna archbishop. It was this anti-Jesuit, episcopal apparatus which Maria Theresa then guided into a coalition with the rising bureaucracy to form the Imperial Censor Commission under the elder van Swieten.

The author rightly insists that the Commission was a result of the empress's momentous decision to realign and centralize the archaic Habsburg administration, rather than an attempt to make the state into the protector of an enfeebled orthodoxy. Van Swieten, the Jansenist liberal, and Archbishop Migazzi were united only in their desire to break the Jesuits' monopoly of the printed word. When van Swieten's associates began moving beyond a reformed Catholicism toward a Staatskirchentum, Migazzi broke the implicit alliance and receded into defensive isolation. The position of the empress, caught between piety and the desire to push forward with secular modernization, remains unclear. Klingenstein agrees with most recent scholars that the Josephinist Staatskirchentum had its roots in the first half of Maria Theresa's reign, but the author's failure to come to grips with the empress's motivation is perhaps the biggest weakness of the volume.

This book is a stimulating and sensitive examination of a topic which has had too little attention in Austrian historiography for three generations. Its organization suffers somewhat as it wavers between a chronological and a topical structure, and occasionally its conciseness exceeds the bounds of even monographic literature. In this particular case, however, the impression that the author's reach has exceeded her grasp is neatly balanced by the happy expectation that the grasp will gain strength.

\section{Philip J. AdLER \\ East Carolina University}

THE EAGLES DIE: FRANZ JOSEPH, ELISABETH, AND THEIR AUSTRIA. By George R. Marek. New York: Harper \& Row, 1974. xix, 532 pp. $\$ 12.50$.

History like war is too important to be left to the professionals. We need the gifted dilettante whose freshness and enthusiasm will redress that pedantic narrowness which is the occupational hazard of the academic scholar. There is a long succession of talented amateurs extending from Lord Macaulay to $H$. G. Wells and to Barbara Tuchman who have made significant contributions to the understanding or the popularization of the past. George R. Marek, unfortunately, does not belong in this company. After a successful career in the world of business and the publication of several books on music and musicians, he has now turned to his native Austria during the reign of Franz Joseph. He brings to this subject charm, wit, sensitivity, and the cultivation of a man of the world. Yet these virtues cannot make up for insufficient training and limited perspective. The book will appeal primarily to that public which seeks in history the theatrical and the piquant. 